\title{
5176 Sayılı Kanun İle Olușturulan KGEK ve Kamu Etik Komisyonlarının İşlevselliği Üzerine Bir Değerlendirme: Adana ve Gaziantep Büyükşehir Belediyeleri Ölçeğinde Bir İnceleme
}

\author{
An Evaluation on the Functionality of the Public Servants Ethics Committee and Public Ethics \\ Commissions Established by Law No. 5176 on the Scale of Metropolitan Municipalities: The Case of \\ Adana and Gaziantep
}

\section{Ekrem ASLAN}

Doktorant, Türkiye Kent Konseyleri Birliği 10.Dönem Başkanı

Ekremaslan2005@gmail.com

https://orcid.org/0000-0001-8829-7301
MakaleBaşvuruTarihi / Received: 24.05.2021

Makale Kabul Tarihi / Accepted : 26.06.2021

MakaleTürü / Article Type: AraştırmaMakalesi
AnahtarKelimeler

Kamu Etĭ̆i,

Belediye, Etik

Komisyon,

Adana,

Gaziantep, KGEK

\section{ÖZET}

Ülkemizde kamu yönetimi çerçevesinde gelişmekte olan bir yönetim anlayışının tezahürü olacak şekilde bazı düzenlemeler yapılmıştır. Bu çerçevede kamuda etik kültürün gelişmesi ve etik bilincin oluşmasına yönelik bir takım yenilikler de yapılmıştır. Kamu yönetiminde etik kültürünün yerleştirilmesi ile ilgili atılan en somut adım 5176 sayılı Kamu Görevlileri Etik Kurulu Kurulması Hakkında Kanun'un yürürlüğe girmesi olmuştur. Kanun kapsamında Kamu Görevlileri Etik Kurulu teşkil edilmiştir. Kurul'a kamuda etik kültürünün geliştirilmesi ile ilgili birçok görev ve sorumluluk verilmiştir. Aynı amaç doğrultusunda 13/04/2005 tarihinde yürürlüğe giren Kamu Görevlileri Etik Davranış İlkeleri İle Başvuru Usul ve Esasları Hakkında Yönetmeliğin 29'uncu maddesi gereğince diğer kamu kurumlarında olduğu gibi belediyelere de Etik Komisyon oluşturma zorunluluğu getirilmiştir. Bu çalışmada Kamu Görevlileri Etik Kurulu ve Belediyeler Etik Komisyonu'nun çalışmaları, işbirlikleri, kurul ve komisyonların yapısal durumları, işleyiş ve sorunları konu edinmiş, birtakım çözüm önerileri ortaya konulmaya çalışılmıştır. Literatür incelemesi ve alan araştırması çalışma yöntemi olarak belirlenmiştir. Alan araştırmasında Adana ve Gaziantep Büyükşehir Belediyesi etik Komisyon üyelerinin görüşleri üzerinden değerlendirmeler yapılmıştır. Çalışma neticesinde belediyelerde kurulan Etik Komisyonlarının yaptırım gücünün olmaması, yasal mevzuatının eksikler içermesi ve kamuoyunda varlığının çok az bilinmesi sebebiyle sembolik bir komisyon olduğu kanısına varılmıştır. Belediyelerde etik yönetim kültürünü yerleştirebilmek ve etik normları uygulayabilmek için, yasal düzenlemelerin ötesinde bu ilkelerin benimsenmesini sağlamak gerektiği sonucuna varılmıştır.
Keywords:

Public Ethics, Municipality, Ethics Commission, Adana, Gaziantep, KGEK

\section{ABSTRACT}

In our country, some arrangements have been made to be a manifestation of a developing management approach within the framework of public administration. In this context, a number of innovations were made for the development of ethical culture and the formation of ethical awareness in the public sector. The most concrete step taken regarding the establishment of an ethical culture in public administration has been the enactment of Law No. 5176 on the Establishment of an Ethics Committee for Public Servants. The Ethics Committee of Public Servants was established within the scope of the law. The Board has been given many duties and responsibilities related to the development of an ethical culture in the public sector. In line with the same purpose, in accordance with Article 29 of the Regulation on the Principles of Ethical Behavior for Public Servants and Application Procedures and Principles, which entered into force on 13/04/2005, municipalities are obliged to form an Ethics Commission, as in other public institutions. In this study, the work of the Public Servants Ethics Committee and the Municipalities Ethics Commission, their cooperation, the structural conditions of the boards and commissions, their functioning and problems are discussed, and some solution suggestions are tried to be put forward. Literature review and field research are determined as the study method. In the field research, evaluations are made on the opinions of Adana and Gaziantep Metropolitan Municipality Ethics Commission members. As a result of the study, it has been concluded that the Ethics Commissions established in municipalities are a symbolic commission because they do not have sanction power, their legal legislation contains deficiencies and their existence is little known in the public. It has been concluded that to establish the ethical management culture in municipalities and to implement ethical norms, it is necessary to ensure the adoption of these principles beyond legal regulations. 


\section{GİRIŞ̧}

Günümüzde küreselleşmenin getirdiği yerelleşme olgusu yerel yönetimleri halkın gerçek bir şekilde yönetime katılmasına daha elverişli, çoğulcu yönetim, karar vericilerin seçmenlerine karşı şeffaf, saydam davranma ve hesap verme sorumluluğu gibi demokrasinin temel ilkelerini daha kolay gerçekleştirmeye olanak tanıyan yapılar haline getirmiştir (Pustu, 2005: 125). Yönetişim adı verilen bu elverişli yönetim şekli özellikle İnsan davranışlarında iyiyi yapıp kötüyü yapmamasını telkin eden bir dizi değerler bütünü olan etik; halkın doğrudan yönetime katılmasına elverişli olan yerel yönetimlerde de sıklıkla kullanılmaya başlanılmıştır.

Yerel yönetimlerde karar alıcı ve uygulayıcılar sorumluluk çerçevesinde toplumun talepleriyle örtüşen kararlar almak zorundadırlar. Bunu gerçekleştirmenin yolu toplumun yapısı hakkında bilgi sahibi olmak, temel ihtiyaç ve önceliklerinin doğru tespiti ile en kısa sürede memnun edici düzeyde beklentilere cevap vermekle mümkündür. Yatkın (2008: 218), yönetimde kaliteli ve etkili hizmetin nitelikli insan eliyle oluştuğunu belirtmiş, "yerel yönetimlerin etkinliğini, çallşanların etik değerleri ve buna bağlı olarak kişilik oluşumlarının belirlediği"ni ifade etmiştir.

Genel olarak, yerel yönetimlerde seçilmiş ve atanmışların yanı sıra çalışanların benimsemesi gereken etik davranış ilkeleri uluslararası alanda kabul edilen "tarafsızlık, hukukilik, dürüstlük, bütünlük, liyakat, sadakat, saydamlık, hesap verilebilirlik, eşitlik, güven ve saygınlık" şeklinde sıralanmaktadır.

Ekonomik İşbirliği ve Kalkınma Örgütü (OECD) bünyesinde çalışmalar yürüten Kamu Yönetimi Komitesi 1998'de yayımladığı "Kamu Hizmetinde Etik Yönetimi İçin Prensipler" başlıklı raporunun çıktısı olarak görülen etik ilkeler ülkemiz kamu etik anlayışı için önemli bir emsal teşkil etmiş bu çerçevede kamu yönetiminde etik yönetim için yasal düzenleme ile yürürlüğe giren 25.05.2014 tarih ve 5176 say1l "Kamu Görevlileri Etik Kurulu Kurulması Hakkındaki Kanun"a dayanılarak hazırlanan Kamu Görevlileri Etik Davranış İlkeleri İle Başvuru Usul ve Esasları Hakkında yönetmelikle Etik Davranış İlkeleri belirlenmiş ve hukuki bir norma dönüştürülmüştür.

Beş bin yüz yetmiş altı sayılı kanunun yürürlüğe girmesiyle birlikte ülkemizde kamu ve yerel yönetimler alanında etikle ilgili birtakım örgütlerin kurulması ve kurumsallaşması sağlanmıştır. Ülkemizde etik ile ilgili iki temel örgütlenme bulunmaktadır. Bunlardan birincisi kamu Görevlilerinin uyması gereken etik davranış ilkelerini belirlemek ve uygulamayı gözetmek üzere Cumhurbaşkanlığı bünyesinde kurulan Kamu Görevlileri Etik Kurulu, ikincisi ise kurum ve kuruluşlarda oluşturulan etik komisyonları ve yetkili disiplin kurullarıdır.

Çalışmamızda kamu yönetimi alanında yerel yönetimler birimi olan Belediyelerde etik çalışmaları incelenmesi amaçlandığı için daha çok yönetsel etik kavramı üzerine odaklanılmış, Kamu kurumlarında da etik ihlallerinin saptanması yaygınlık düzeyinin belirlenmesi ve önlenmesi amacıyla yapılan politik düzenlemeler, alandaki akademik çalışmalar incelenerek etik ihlallerin giderilmesi ve önlenmesi ve kamu çalışanlarında etik bilinç düzeyinin arttırılması amacıyla 5176 Sayılı Kanun kapsamında oluşturulan Kamu Görevlileri Etik Kurulu ile Belediye Etik Komisyonlarının faaliyetleri ve işlevsellikleri hakkında bir takım bulgulara ulaşılmıştır. Bu bulgularla birlikte yerel yönetimlerde etik bilincin yaygınlaştırılması ve etik ihlallerin önlenmesi için çalışmalarda bulunan etik komisyonların ve Kamu Görevlileri Etik Kurulunun işlevsellik düzeyinin ortaya konulması amaciyla İki Büyükşehir Belediyesi'nden (Adana ve Gaziantep) 6 Etik Komisyon üyesi ile mülakat yöntemi ile gerçekleştirilen alan araştırmasının sonuçlarına yer verilmiştir.

\section{ETÍĞE İLISSTKIN KAVRAMSAL ÇERÇEVE}

\subsection{Etik Kavramı}

Yaklaşık 25 yüzyıllık bir geçmişe sahip olan, Yunanca "ethos" dan türetilen etiğin kavramsal çerçevesi ve betimlenmesi konusunda düşünür ve bilim adamlarının ortak bir kanıya varmaları mümkün olmamış, günümüze kadar pek çok etik tanımı yapılmıştır. Fidan (2007)'a göre "Ethos" kelimesi en genel anlamda; bir kültürün bir topluluğun özgün karakteri, ruhu ya da tını (ayırt edici özellik)" anlamına gelmektedir. "Ethos" Yunan felsefesinde karakter, kişilik ve adalet anlamında kullanılmıştır (Fidan, 2007:269).

Etik, kişinin davranışlarına temel olan ahlaki ilkelerin bütünüdür. Bir başka deyişle Etik insana işlerin nasıl yapılması gerektiğini belirleyen rehber değerler, ilkeler ve standartlar manzumelerinin olduğu ve bu manzumelerin karar alma ve uygulamada etken olduğu bir süreci ifade eder.

Etik günümüzde çeşitli mesleklerin icrasında uyulması gereken normların başında gelmektedir. Siyasette, yargıda, iş hayatında, eğitimde, bilim, sanat ve medyada etik değerler ön planda olmaktadır. Çalışmamızda 
kamu birimi olarak ifade edilen yerel yönetimlerde etiğin incelenmesi söz konusu olacağından dolayı daha çok yönetsel etik kavramı ele alınacaktır.

Çoğu zaman birbirine benzer anlamlar olarak ifade edilen "Ahlak" ve "Hukuk" ile etiğin bağlantılı ve iç içe olduğu söylenebilir. Ahlak, "bir kişinin, zümrenin, halkın, ulusun bir kültür grubunun belirli bir tarihsel süreçte yaşamına girerek etkileşime sebep olan ve eylemlerini yönlendiren inanç, değer, norm, buyruk, yasak ve tasarımlar topluluğu ve ağı" "olarak karşımıza çıkarken (Doğan, 2010: 23) etik ise, "toplum içerisinde oluşmuş örf ve adetlerin, değer yargllarının, normların ve kuralların oluşturduğu sistemin bütününü inceleyen bir bilim dalı" olarak karşımıza çıkar (Aktan, 1999: 16).

Etik ile iç içe ele alınması gereken bir diğer kavram olan hukuk, toplumsal yaşama yön veren önemli normatif kuralların başında gelmektedir. Etik kuralların da toplumsal yaşama yön vermede önemli bir rolü olmaktadır. Bu iki kavramın kesiştiği kavram olarak adalet kavramı göze çarpmaktadır. Genel olarak hukukun suç saydığı eylemlerin büyük çoğunluğu etiksel açıdan da kabul edilmeyen yanlış eylemlerdir. Ancak etik açısından uygun bulunmayan davranış ve uygulamalar mevzuatta suç olarak sayılmayabilmekte olup, herhangi bir etik ihlale karşı cezai yaptırım söz konusu olmayabilmektedir. Nitekim Yüksel'e (2005) göre "hukukta yaptırım maddidir ve suç işleyenlere kanuni ceza verilir. Etikte ise geleneksel olarak yaptırım manevidir ve cezasını vicdanı verir" (Yüksel, 2005: 59).

\subsection{Yönetsel Etik}

Etiğin kamu yönetimi alanındaki karşı1lığı olarak yönetsel etik kavramı karşımıza çıkmaktadır. Öztürk (2009: 303), yönetsel etiği “örgütlerin amaç ve süreçlerini tanımlayan yasalar, yöneticilerin ve diğer çalışanların nasıl davranması ve neyi yapıp neyi yapmamaları gerektiğini belirleyen ilkeler bütünü" olarak ifade etmiştir.

Yönetsel etik; bireylerin, zümrenin, grubun, ulusun karar alması ve kararın uygulanması sürecinde uyulması gereken ilkeler veya davranış kurallarıdır. Özellikle kamusal yönetim alanlarında karar alma ve uygulama süreçlerinde toplumsal normlarla uyuşmayan davranış ve uygulamaların yaygınlaşması kurumları etiğe, etik bilinci geliştirmeye ve bunları kültürel bir yaşam biçimi haline getirmeye yönlendirmektedir.

Yönetim alanındaki yönetsel etik tanımı Aydın'a göre (1998: 6),

(...) yönetim alanındaki yönetsel etik tanımını yönetsel kararların verilmesinde tutarlı, tarafsız ve gerçeklere dayalı olarak, herkes için en iyi olacak eylemleri seçmeyi ve bu eylemlerde adalet, eşitlik, tarafsızlık, dürüstlük, sorumluluk, açıklık, sevgi, hoşgörü gösterme gibi evrensel değerleri esas alan ve siyasetçiler ile bürokratların kamu hizmetlerini sunarken, yol gösterici olan davranış ilkeleridir.

Yatkın (2008: 216), yönetsel etiğin pozitif ve negatif olmak üzere iki farklı konusunun olduğunu belirtmiştir. Yönetsel etiğin bu iki konusu Kahraman'a göre (2010: 52),

(...) Olumlu anlamda yönetsel etik, kişilerin sahip oldukları ahlaki ve etik değerleri bulundukları çevrelere yansıtmalarıdır. Bir başka deyişle adaletli ve ahlaklı davranmalıdırlar. Kamuda veya yerel yönetimlerde çalışan kişilerin sorumluluklarındaki görevleri nitelikli bir şekilde ve zamanında yapmaları, aldıkları ücretlerin karşılığını vermeleri, yöneticilerine karşı sorumluluk bilinciyle hareket etmeleri olumlu anlamda yönetsel etik olarak nitelendirilebilirler.Olumsuz anlamıyla yönetsel etik ise, bireylerin ahlaki ve etik değerlere uymayıp kurum ya da zümreleri sıkıntılı duruma sokarak bireysel kazanç sağlamak amacıyla mevcut görevlerini aksatmaları veya haksız kazanç elde etmeleridir .

Kamu'da özellikle belediyelerde yolsuzluk, rüşvet, irtikap, zimmete para geçirme, resmi evraklarda sahtecilik olumsuz yönetsel etik türleri olarak bilinmektedir.

\section{KAMU YÖNETIMINDE ETIKK ÇALIŞMALARA ILIŞKİN ARAŞTIRMA BULGULARI VE ANALIZI}

\subsection{Mevzuat Ve Literatür İncelemeleri İle Elde Edilen Bulgular ve Analizi}

Ekonomik İşbirliği ve Kalkınma Örgütü (OECD) bünyesinde çalışmalar yürüten Kamu Yönetimi Komitesi 1998'de yayımladığı "Kamu Hizmetinde Etik Yönetimi İçin Prensipler” başlıklı raporunun çıktısı olarak görülen etik ilkeler ülkemiz kamu etik anlayışı için önemli bir emsal teşkil etmiş bu çerçevede kamu yönetiminde etik yönetim için yasal düzenleme ile yürürlüğe giren 25.05.2014 tarih ve 5176 say1l "Kamu Görevlileri Etik Kurulu Kurulması Hakkındaki Kanun”a dayanılarak hazırlanan Kamu Görevlileri Etik Davranış İlkeleri İle Başvuru Usul ve Esasları Hakkında yönetmelikle Etik Davranış İlkeleri belirlenmiş ve hukuki bir norma dönüştürülmüştür. 
Kamuda seçilmiş ve atanmışların yanı sıra çalışanların etik davranmalarına ilişkin en temel düzenlemeler 1982 Anayasası'nda yer almaktadır. 1982 Anayasasının "Kanun Önünde Eşittlĭgi” düzenleyen 10, "Mal Bildirimini”" düzenleyen 71, "Dilekçe ve Bilgi Edinme ve Kamu Denetçisine Başvurma Hakkinı" düzenleyen 74, Memurlar ve Diğer Kamu Görevlilerinin Sorumluluklarını düzenleyen 129 ve "kanunsuz emri” düzenleyen 137'nci maddeleri kamuda etik davranışların yaygınlaştırılması ve etik ihlallerinin önlenmesinin anayasal güvencesi olarak düzenlenmiştir (T.C. 1982 Anayasası, 1982).

Bin dokuz yüz altmış beş tarihli, 657 sayılı Devlet Memurları Kanunu'nda etik davranış ilkelerinin benimsenmesi, etik ikilem ve ihlallere neden olacak bazı çıkar çatışması durumlarını ortadan kaldıracak düzenlenmeler yer almıştır. Sırasıyla Devlet Memurları Kanunu'nun 1'inci Kısmının 2, 3, 4, 7 ve 8 inci bölümlerinde kamu görevlilerinin davranış kuralları ve yaptırımlarla ilgili ayrıntılı kurallar bulunmaktadır. 657 Sayılı Devlet Memurları Kanununa göre (657 Sayılı DMK, 1965): "Devlet memurlarl görevlerini tarafsız bir biçimde yerine getirmek ve devlet menfaatini korumak zorundadı"” (md. 7). "Devlet memurları konusu suç olan bir emri hiçbir şekilde yerine getiremez, böyle bir emri yerine getiren kişi sorumluluktan kurtulamaz" (md. 11). Devlet memurları kendileri, eşleri ve çocukları için mal beyanında bulunur" (md. 14). Ayrıca devlet memurları, "Türk Ticaret Kanunu hükümlerine göre tacir veya esnaf sayllmalarını gerektirecek bir faaliyette bulunamazlar" (md. 28). Buna ek olarak kanuna göre, kamu görevlilerinin hediye almaları ve menfaat sağlamaları da yasaklanmıştır (md. 29). İzleyen maddede devlet memurlarının çalıştığı ya da mensubu olduğu kurumdan her ne ad ile anılırsa anılsın herhangi bir menfaat sağlamasının yasak olduğu belirtilmiştir (md. 30) ve yine devlet memurlarının kamu hizmetleri ile ilgili gizli bilgileri görevlerinden ayrılmış olsalar bile açıklamaları yasaktır (md. 31) (657 Sayılı DMK, 1965).

Yerel yönetimlerde etik davranışları düzenleyen ve güvence altına alan bir diğer kanun ise 5237 sayılı "Türk Ceza Kanunu"dur. Etik dışı davranışların cezai sorumluluğunu belirleyen düzenlemeler bu kanunla yapılmıştır. Etik ihlallerinin başında gelen rüşvet, irtikâp, zimmet, ihaleye, alım ve satıma hile ve fesat karıştırma gibi haller yolsuzluk suçu olarak tanımlanmakta olup Türk Ceza Kanunda yasal suç olarak tanımlanmıştır. Aynı zamanda yolsuzluk suçu olmayıp da önemli çıkar çatışması etkeni olan görevi ihmal ve kamu görevi suiistimali gibi suçlarda aynı kanunla düzenlenmiştir. Türk Ceza Kanunu'nun "Kamu görevlisi”" başlıklı 6'1ncı maddesi, "Güveni Kötüye Kullanma” başlıklı 155'inci maddesi "Resmi Belgede Sahtecilik" başl1klı 204'üncü maddesi, "Resmi Belgeyi Bozmak, Yok Etmek Veya Gizlemek" başlıkl 205'inci maddesi, "İhaleye Fesat Karıştırma”" başlıklı 235'inci, "Edimin İfasına Fesat Karıştırma" başlıklı 236'ınc1 maddesi, "Zimmet" başlıklı 247'inci maddesi, "Irtikap" başl1kl 250'inci maddesi, "Denetim Görevinin İhmali"başlıklı251'inci maddesi, "Rüşvet" başl1klı 252'inci maddesi, "Nüfuz Ticareti" başlıklı 255'inci maddesi, "Görevi Kötüye Kullanma" başl1klı 257'inci maddesi, "Göreve İlişkin Sırrın Açıklanması" başlıklı 258'inci maddesi, "Kamu Görevlisinin Ticareti" başl1klı 259'uncu maddesi, “Kamu Görevine Ait Araç ve Gereçleri Suçta Kullanma” başlıklı 266'ıncı maddesi ve "Suçtan Kaynaklanan Mal VarlığıDeğerlerini Aklama" başlıklı 282'inci maddesi suç unsuru teşkil eden ihlallerin yanı sıra aynı zamanda etik ihlalleri olarak cezai yaptırımlara dayanak oluşturmaktadır (5237 Sayılı TCK, 2004). 5237 sayılı Türk Ceza Kanunu aynı zamanda bu maddeler 1şığında zarara uğrayanları korumaktadır. Kanunla etiğin kamu görevlilerini etkilemesine yardımcı olunmaktadır.

Üç bin altı yüz yirmi sekiz sayılı "Rüşvet ve Yolsuzluklarla Mücadele Kanunu" da kamu yönetimi sistemimizde etik altyapının yasal çerçevesini oluşturan önemli kanunlardandır.Kanunun temel amacı kamu çalışanlarını gelirleriyle orantılı olarak edindiği malların haksız kazanç olup olmadığını belirlemektir.

Kamu Görevlileri Etik Kurulu kararları ve incelemelerine baktığımızda yerel yönetimlerde sıkça görülen etik ihlal türlerinin eş, dost akraba kayırmacılığı (nepotizm), ve politik kayırmacılığın (patronaj) yanı sıra hizmet kayırmacılı̆gı olduğunu görmekteyiz. Buradan hareketle Türk hukuk sistemimizin kayırmacılık eylemlerini önleyecek yeterli alana sahip olmadığını belirtebiliriz. Mobbing'in (Psikolojik Taciz) Ceza yasamızda suç olarak düzenlenmiş olmaması da önemli bir sorundur.

Akdeniz (2016), “Türkiye'de Yerel Yönetimler Tarafından Hizmet Sunumu Esnasında Gerçekleştirilen Etik İhlalleri" adlı çalışmasında yerel yönetimlerde etik İhlallerin; "Kamu Alım Ve Satımları,İmar Planı Değişiklikleri, Emsal Değişiklikleri, Ruhsat İşlemleri, Yoğunluk Artışı,Parselasyon ve Yoldan İhdas İşlemleri, İdari Yargı Kararlarının Uygulanmaması,Geciktirilmesi ya da Dolanarak Uygulanmast, İse Alma, Atama ve Yükselme Işslemlerinde Kayırmacılık ve Hizmet Kayırmacılığı, Belediye Şirketleri ve Isştirakleri, Mahalli İdare Birliklerinde İstihdam Ve Denetim Sorunları, Belediyelerce Yapılan Yardım ve Bă̆ışlar, Hediyeler, İkramlar, Savurganlık, Şeffaflı, Hesap Verebilirlik, Belediye Kanununun 28'inci Maddesi Hükmüne Aykırılık ve Çıkar Çatışması, İmar Kanunu 18'inci Maddeye Aykırılık, Psikolojik Taciz (Mobbing)” alanlarında yoğunlaştığını ifade etmiştir (Akdeniz, 2016). 
Küçükyağc1 (2017), "Bir Politika Transferi Örneği Olarak Türkiye'de Etik Yapılanma" adlı makalesinde; "ülkemizde daha çok etik yapılanma ve düzenlemelere yönelik uygulamaların Avrupa Birliği”ne uyum kapsamında yolsuzlukla mücadele politikalarının bir sonucu olarak gelişmis ülkelerin kamu yönetimine ilişkin etik uygulamaların Türk kamu yönetimine aktarlması" ş̧eklinde olduğunu ifade etmiştir. Avrupa Birliği Uyum yasaları kapsamında Türk Kamu Yönetiminde etik kültürünün yerleştirilmesi ile ilgili atılan en somut adımın 5176 sayılı Kamu Görevlileri Etik Kurulu Kurulması Hakkında Kanun 'un yürürlüğe girmesi akabinde 2005 yılında Kamu Görevlileri Etik Davranış İlkeleri İle Başvuru Usul ve Esasları Hakkında yönetmeliğin yayımlanması olduğunu söylemek mümkündür. Bu çerçevede ayrıca 5176 sayılı kanuna dayanak olacak şeklide Kamu Görevlileri Etik Kurulu oluşturulmuş, kamu görevlilerinin uymaları gereken etik davranış ilkeleri dağınık bir mevzuattan kurtarılarak gözden geçirilmiş, Kurul'a kamuda etik kültürünün geliştirilmesi ile ilgili birçok görev ve sorumluluk verilmiştir.

Kamu Görevlileri Etik Kurul'u 11 kişiden oluşmaktadır.Kamu görevlileri Etik Kurul Üyeleri kanun maddesi gereğince Cumhurbaşkanı tarafından belirli kurumlara ayrılan kontenjan kapsamında atama yoluyla belirlenmektedir. Kurul Başkan ve Üyeliklerine Atama Yapılan Kontenjan sayısı tablo 2.1'de sunulmştur.

Tablo 2.1Kurul Başkan ve Üyeliklerine Atama Yapılan Kontenjanlar (KGEK, 2020)

\begin{tabular}{|c|c|}
\hline $\begin{array}{c}\text { Kontenjan } \\
\text { Sayısı }\end{array}$ & Kurul Başkan ve Üyeliklerine Atama Yapılan Kontenjanlar \\
\hline 1 & Bakanlık Görevi yapmış olanlar arasından bir üye \\
\hline 1 & İl Belediye Başkanlığı yapmış olanlar arasından bir üye \\
\hline 3 & $\begin{array}{c}\text { Yargıtay, Danıştay, Sayıştay üyeliği görevlerinden emekliye ayrılanlar } \\
\text { arasından üç üye }\end{array}$ \\
\hline 3 & $\begin{array}{c}\text { Müsteşarlık, büyükelçilik, valilik, bağımsız ve düzenleyici kurul } \\
\text { başkanlığı görevlerinde bulunmuş veya bu görevlerden emekliye } \\
\text { ayrılanlar arasından üç üye }\end{array}$ \\
\hline 2 & $\begin{array}{r}\text { Üniversitede rektörlük veya dekanlık görevlerinde bulunmuş öğretim } \\
\text { üyeleri veya bunların emeklileri arasından iki üye }\end{array}$ \\
\hline 1 & $\begin{array}{r}\text { Kamu kurumu niteliğindeki meslek kuruluşlarında en üst kademe } \\
\text { yöneticiliği yapmış olanlar arasından bir üye }\end{array}$ \\
\hline
\end{tabular}

Kamu Görevlileri Etik Kurulu'nun (2005), başlıca görevleri (Resmi Gazete, 2005):

- Kamu görevlilerinin görevlerini yürütürken uymaları gereken etik davranış ilkelerini belirlemek.

- Etik davranış ilkelerinin ihlâl edildiği iddiasıyla re'sen veya yapılacak başvurular üzerine gerekli inceleme ve araştırmayı yapmak.

- Kamuda etik kültürünü yerleştirmek üzere çalışmalar yapmak veya yaptırmak ve bu konuda yapılacak çalışmalara destek vermek.

- Hediye alma yasağının kapsamını belirlemek ve uygulamasını izlemek

- Kurum ve kuruluşların, etik davranış ilkeleri konusunda uygulamada karşılaştıkları sorunlara yönelik olarak görüş bildirmektir.

İki bin beş tarih ve 25785 sayılı ResmiGazete'de yayımlanan yönetmelik gereğince (R.G.25785, 2005):

(...) Kamu kurumları ve yerel yönetimlerde oluşturulan Etik Komisyonlar kurum içinden az üç kişiden oluşmaktadır. Etik komisyonunun üyelerinin ne kadar süreyle görev yapacağ ve diğer hususlar, kurum ve kuruluşun üst yöneticisince belirlenir. Etik komisyonu üyelerinin özgeçmiş ve iletişim bilgileri, üç ay içinde Kamu Görevlileri Etik Kurulu'na bildirilir (md.29). 
Kurul ile işbirliği içerisinde çalışan Etik Komisyonları'nın işlevleri yine “Kamu Görevlileri Etik Davranış İlkeleri İle Başvuru Usul Ve Esasları Hakkında Yönetmelik"de"Kurum ve kuruluşlarda, etik kültürünü yerleştirmek ve geliştirmek. Personelin etik davranış ilkeleri konusunda karşılaştıkları sorunlarla ilgili olarak tavsiyelerde ve yönlendirmede bulunmak. Etik uygulamaları değerlendirmek"ş̧eklinde belirtilmiştir (R.G.25785, 2005).

Ülkemizde etik üzerine yapılan bilimsel çalışmalarda daha çok Kamu Görevlileri Etik Kurulu üzerine odaklanılmış, kurulun işlevselliği, etik ihlalleri ve uygulamalarla ilgili saptamalara varılmıştır. Kamu Görevlileri Etik Kurul'un ülkemiz yönetim sisteminde uygulanmasının yeni olması bu alandaki çalışmaların varlığını sınırlandırmıştır. Ülkemizde Kamu Görevlileri Etik Kurulu'nun aksine yerel yönetim birimi olan belediyelerde oluşturulan "Etik Komisyon"lara ilişkin doğrudan ve kapsamlı bir bilimsel çalışma yapılmadığı sonucuna yapılan araştırmalar neticesinde varılmıştır.

Etik komisyonlara ait bilgilere, kurumların resmi internet sitesine erişim sağlayarak ulaşılabilmektedir. Araştırma kapsamında Adana Büyükşehir Belediyesi ve Gaziantep Büyükşehir Belediyesi web sitesi incelenmiş, her iki belediye etik komisyonu hakkında veri ve bilgi paylaşımını internet ortamında erişimi mümkün kılmıştır. Adana Büyükşehir Belediyesine ilişkin Web Sayfası incelendiğinde Belediye'nin etik Haftası dolayısıyla yapmış olduğu 2012 tarihli faaliyet ve Kamu Görevlileri Etik Sözleşme maddeleri ile ilgili bilgilere ulaşılmıştır.

İncelemeye konu olan bir diğer belediye, Gaziantep Büyükşehir Belediyesi web sitesine erişim sağlandığında Etik Komisyonu sayfasının mevcut olduğu görülmektedir. Sayfa içerisinde etik komisyon üye bilgileri, Kamu Görevlileri Etik Davranış İlkeleri, Kamu Görevlileri Etik Sözleşmesi ve Kamu Etik Kurulunun Çalışma Yapısı hakkında bilgiler verilmiştir.

Her iki Büyükşehir Belediyesi etik ihlalleri önlemeye ve kamuda etik bilincin arttırılmasına yönelik yapmış oldukları çalışmalara ait bilgilerin internet sitesinde kısıtlı olduğu düşüncesinden hareketle belediyelerin İnsan Kaynakları Daire Başkanlığı Eğitim Şube Müdürlüğü ile iletişime geçilmiş ve çalışmalar hakkında detaylı bilgilere ulaşılmıştır. Gaziantep Büyükşehir Belediyesi Eğitim Şube Müdürlüğü verilerine göre kurum kültürünün gelişmesi ve etik bilincin oluşmasına yönelik eğitimlerden bugüne kadar 1100 kamu görevlisi yararlanmıştır. Gaziantep Büyükşehir Belediyesi İnsan Kaynakları Daire Başkanı görüşme esnasında Zabıta personeli öncelikli olmak üzere ilgili personellere etik eğitimleri verildiği bilgisini paylaşmıştır.

Etik komisyon üyeleri ile yapılan görüşmede Etik İhlale ilişkin komisyona havale edilen herhangi bir dosya ile karşılaşılmadığı bilgisine ulaşılmıştır. Yine her iki Belediye yetkilileri ile yapılan görüşmede Kamu Görevlileri Etik Kurulu'nun yerellerde yapmış olduğu çalışmalara katılım gösterdikleri ve kurumla etkileşim halinde oldukları sonucuna ulaşılmıştır.

Pabuccu (2018), Kamu Görevlileri Etik Kurulu üzerine yapmış olduğu izleme neticesinde Kurul'un “kamuda etik kültürünün yaygınlaştırllmasına yönelik faaliyetlere etik ilkelerin belirlenmesi ve re'sen (kendiliğinden) ya da başvuru üzerine yaptı ̆̆ inceleme faaliyetlerinden daha fazla önem verdiğ $i$ " kanısına varmıştır. Nitekim kamu görevlileri Etik Kurul'u çalışmalarını incelediğimizde 2008-2020 yılları arasında ağırlıklı olarak kamu personeline yönelik etik kodların ve etik kültürün yaygınlaştırılması eğitimlerine önem verildiği görülmektedir. Bu eğitimler Ankara merkezli kurumlar olmak üzere birçok ili kapsamaktadır. Çalışmaları genellikle ulusal bir kampanya şeklinde ya da proje bazlı olarak yürütmektedir. Kurumlardan gelen talepler değerlendirmekte, bu doğrultuda eğitimler verilmektedir. Corona Virüsü salgın döneminde ağırlıklı olarak eğitimler çevrimiçi düzenlenmiştir. 2020 y1lında, on yedi kamu kurumunda 3823 kişiye erişilmiş ve eğitim verilmiştir (KGEK,2020: 15). 2020 y1lı içerisinde 17 eğitimin dokuz (9) tanesi yüz yüze, sekiz (8) tanesi çevrim içi gerçekleştirilmiştir. 2015-2020 yılı arasında Kurumlarda eğitim verilen personel sayısı Tablo 2.2'de verilmiştir. 
Tablo 2.2: Kamu Görevlileri Etik Kurulu tarafından 2020 y1lı içerisinde Eğitim Verilen Kurumlar ve Personel Sayı1

\begin{tabular}{|c|c|c|c|c|c|c|}
\hline & $\begin{array}{l}\text { Başbakanlık/ } \\
\text { Bakanlıklar }\end{array}$ & $\begin{array}{l}\text { Bağlı İlgili } \\
\text { Kuruluşlar }\end{array}$ & $\begin{array}{c}\text { Valilik/ } \\
\text { Kaymakamlık }\end{array}$ & Belediyeler & $\begin{array}{c}\text { Kamu } \\
\text { Kurumu ve } \\
\text { Kuruluşu } \\
\text { Niteliğindeki } \\
\text { Meslek } \\
\text { Kuruluşları }\end{array}$ & $\begin{array}{c}\text { Eğitim } \\
\text { Alan } \\
\text { Toplam } \\
\text { Kişi } \\
\text { Sayisı }\end{array}$ \\
\hline 2008 & 500 & 475 & 100 & 65 & 150 & 1290 \\
\hline 2009 & 1415 & 1352 & 1000 & 2150 & 1098 & 7095 \\
\hline 2010 & 160 & 4127 & 2081 & 410 & 1284 & 8062 \\
\hline 2011 & 2780 & 535 & 963 & 733 & 1283 & 6294 \\
\hline 2012 & 529 & 1577 & 360 & 1125 & 668 & 4259 \\
\hline 2013 & 800 & 620 & 80 & 880 & 285 & 2665 \\
\hline 2014 & 1904 & 891 & 450 & 360 & 60 & 3665 \\
\hline $\begin{array}{l}2015- \\
2016\end{array}$ & 230 & 664 & 504 & 505 & 492 & 2395 \\
\hline 2017 & 224 & 627 & 20 & 476 & 60 & 1407 \\
\hline 2018 & 345 & 2170 & 60 & 245 & 55 & 2875 \\
\hline 2019 & 408 & 1386 & 450 & 1483 & 205 & 3932 \\
\hline 2020 & 1475 & 1619 & 251 & 363 & 115 & 3823 \\
\hline Toplam & 10770 & 16043 & 6319 & 8795 & 5755 & 47762 \\
\hline
\end{tabular}


Şekil 2.1: Etik Eğitimi Alan Kurumlar ve Personel Sayısı

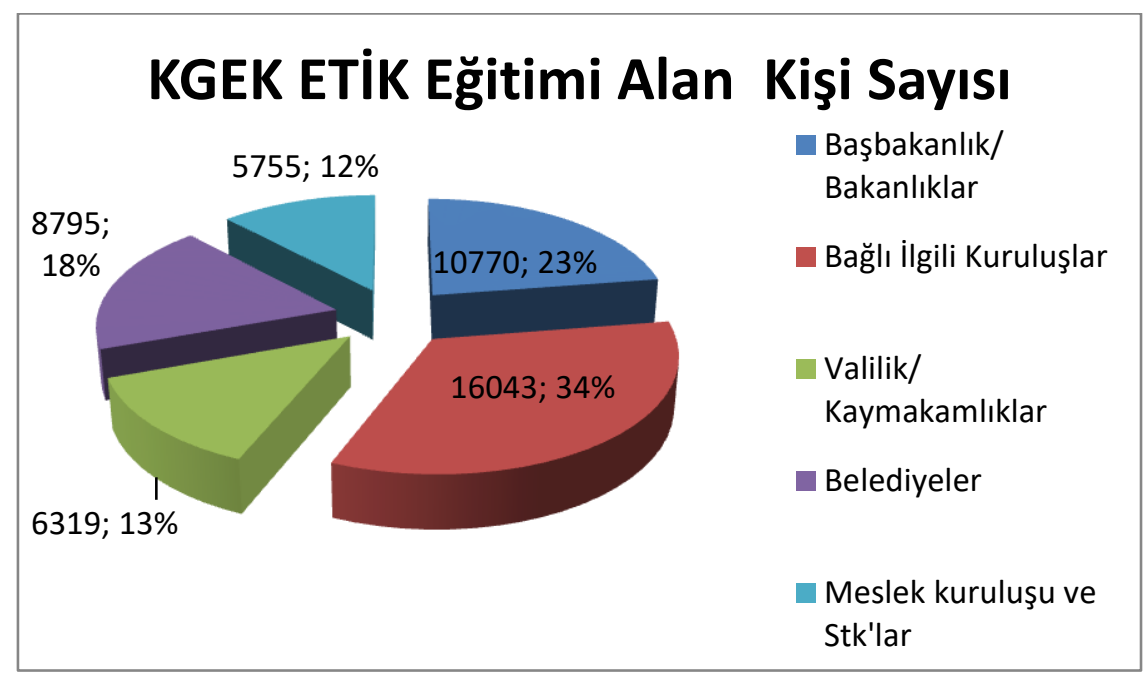

Kamu Görevlileri Etik Kurulu Personeli ve kurumun gerçekleştirdiği 'Etik Eğitici Programı'ndan mezun olan eğitmenler tarafindan kurumlardan gelen talepler doğrultusunda 2008-2020 yılları arasında toplam 47762 personele etik eğitimi verilmiştir. Etik ihlallerin en fazla olduğu kurumlardan olan belediyelerden 2008-2020 yılları arasında 8795 personel eğitimlerden yararlanmıştır. Bu oran toplam eğitim alan personel sayısının $\% 18$ 'ine denk gelmektedir.

Kamu Görevlileri Etik Kurulunda kamu kurumlarında etik farkındalı̆̆ının arttırılması ve etik bilincin güçlendirilmesi için kurum personeline etik sorumluluk yüklemek gerektiği anlayışı hakim olmuştur. Bu anlayıştan hareketle Etik Kurulu tarafından etik eğitimlerin yanı sıra, "Etik Liderlik Programları" düzenlenmiştir (KGEK,2019). Program kapsamında toplam 205 kişi Etik Lider unvanına sahip olmuştur.

Kamu Görevlileri Etik Kurulu'nun 5176 Sayılı Kanuna dayanak olacak şekilde çıkarılan Kamu Görevlileri etik Davranış İlkeleri Başvuru Usul ve Esasları Hakkında yönetmelik uyarınca; başvuru üzerine veya resen yürütülen inceleme ve araştırma sonucunda hakkında iddiada bulunan kamu görevlisi hakkında inceleme yapma yetkisi vardır. İnceleme yapılan kamu görevlisinin savunmasının talebi, değerlendirilmesi neticisinde etik ihlalin varlığına veya kamu görevlisinin davranışının etik ilkelere aykırı olup olmadığına dair bir karar verme ve bildirme yetkisine haizdir. 2005-2020 yılları arasında Kamu Görevlileri Etik Kuruluna yapılan toplam başvuru sayısı 2562adettir.İncelemeye ve değerlendirmeye alınan dosyaların konularına ve sonuçlarına göre dağılımı tablo ve şekil halinde verilmiştir.

Şekil 2.2: 2005-2020 Yı1ları arasında Kamu Görevlileri Etik Kuruluna yapılan başvuru sayısı

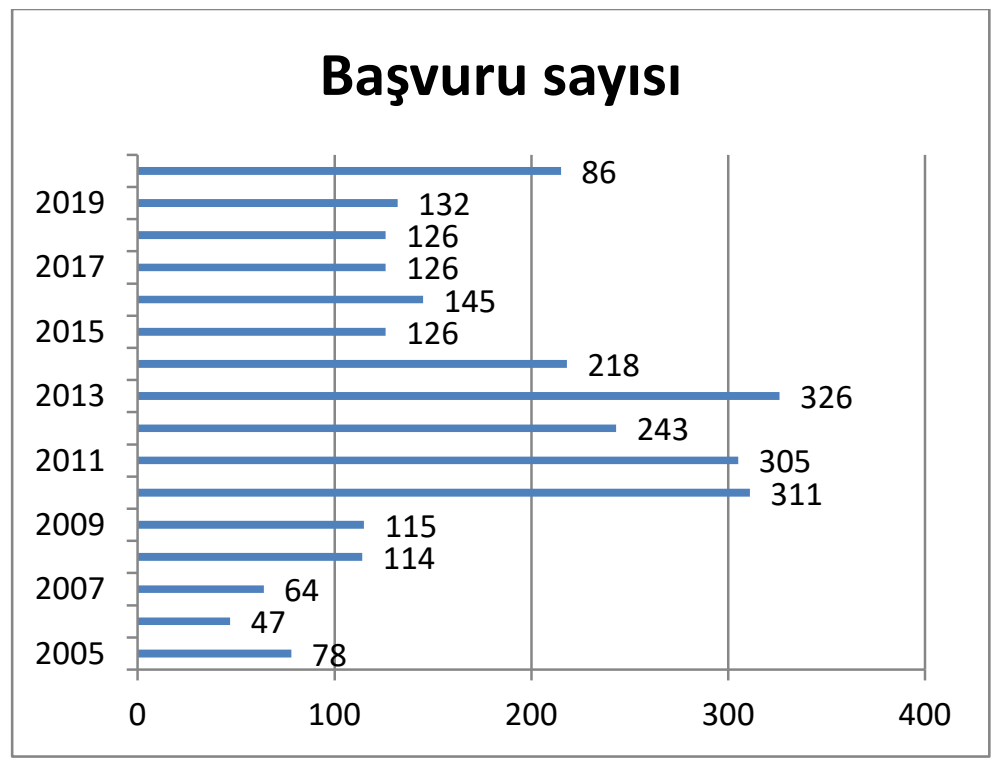


Etik ihlali başvurusu söz konusu olduğunda Kurul bunun başvuru usulüne göre inceleme yapabilme yetkisine sahip olması durumunu göz önüne alarak başvuru uygunluğunu değerlendirmektedir. Ayrıca başvuru yapıldığında konu ile ilişkili yargıya taşınmış bir dava söz konusu ise, başvuru yargıya intikal ettiğinden dolayı usul yönünden reddedilmektedir. 2005-2020 yılları arasında Kamu Görevlileri Etik Kuruluna başvuru yapılan dosyalardan 1830 adeti usule aykırılık nedeniyle incelemeye alınmamıştır. 2005-2020 yılları arasında başvuru yapılan 2562 adet toplam başvuru' dan 732 adeti incelemeye alınmıştır.

Şekil 2.3: Kamu Görevlileri Etik Kuruluna Yapılan Başvuruların Dağılımı

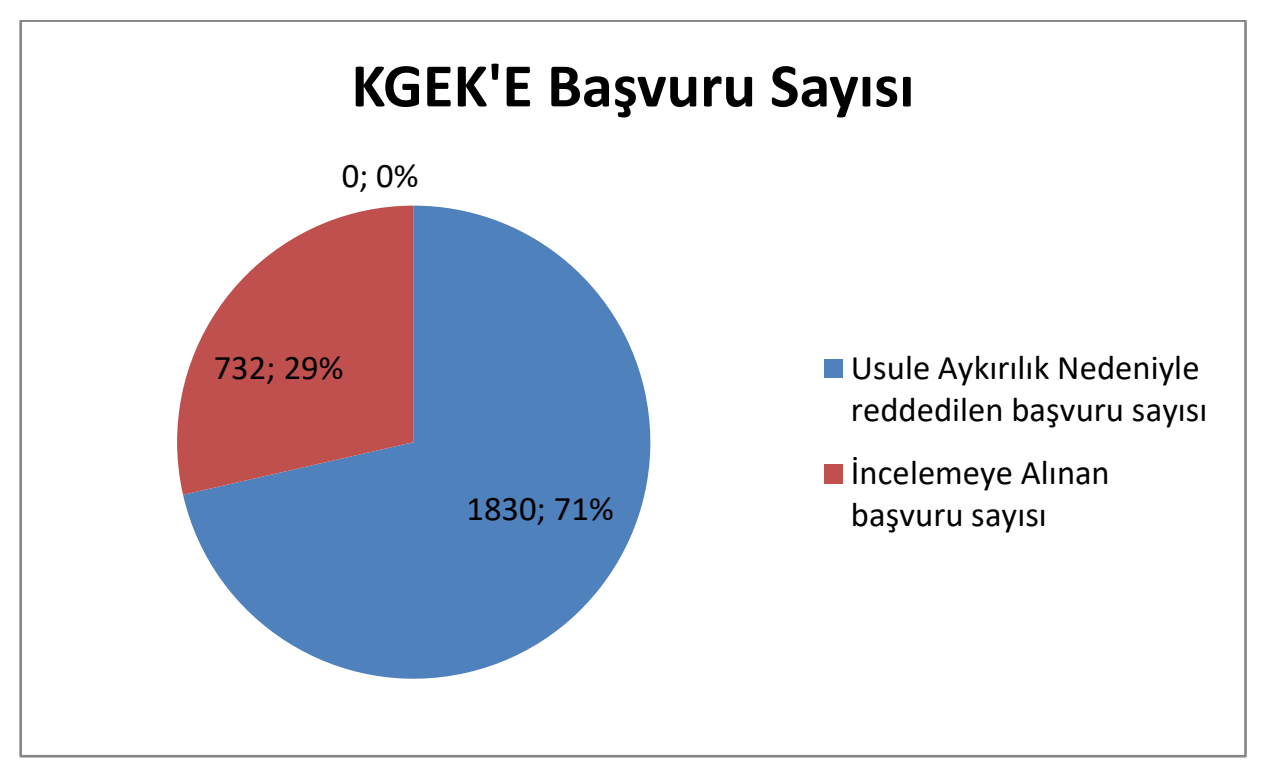

Şekil 2.3'de görüldüğü üzere Kamu Görevlileri Etik Kuruluna yapılan başvuruların büyük çoğunluğu Kurulun usulen inceleme yetkisine haiz olmaması nedeniyle geri çevrilmiştir. Sonuçlardan anlaşıldı̆̆ı üzere Etik ihlal oluştuğu düşüncesiyle başvuru yapanlarınEtik Kurulu görev ve yetkileri hakkında gerekli bilgiye sahip olmadığ 1 görülmektedir. Bu nedenledir ki Etik Kurul'un çalışmaları ve yetkileri ile ilgili bilgilendirici faaliyetlere ağırlık verilmesi gerekmektedir.

İncelemeye uygun görülen 732 başvurudan sadece bu zamana kadar 98 Adeti hakkında etik ihlal kararı verilmiştir. Bu kararların kamu görevlilerinin unvan ve kurumlarına göre dağılımı Şekil 2.4'degösterilmiştir.

Şekil 2.4:Etik ihlal nedeniyle haklarında inceleme yapılan kamu görevlilerinin makamlarına göre dağılımı

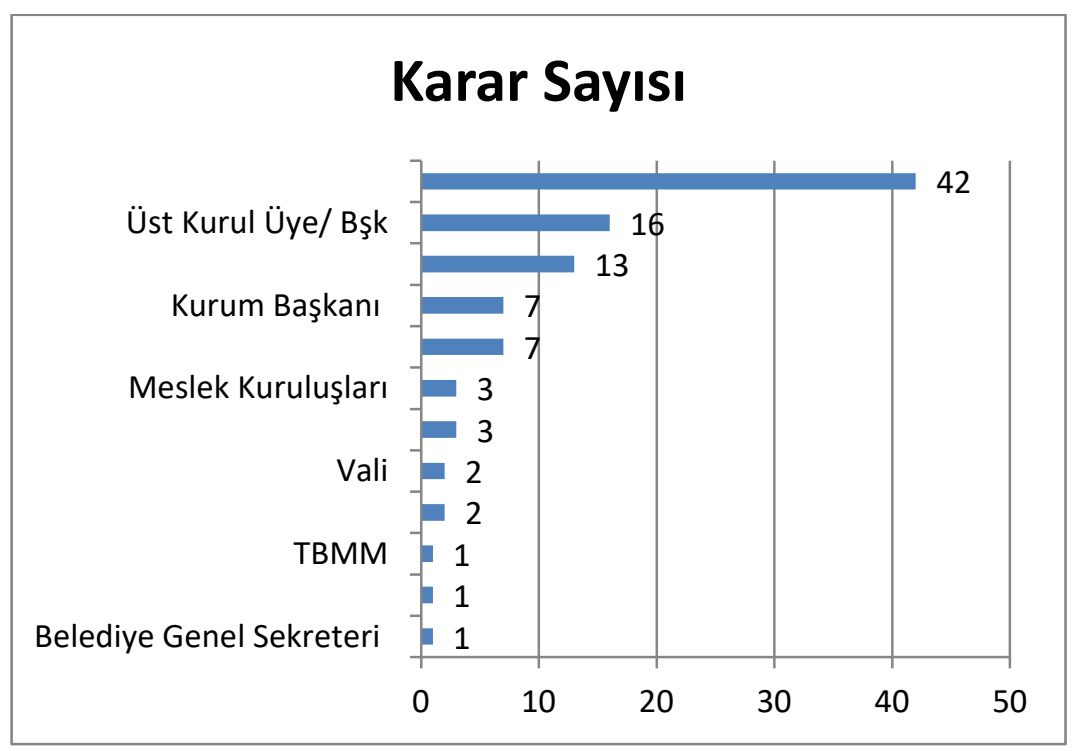


Kurul kararları incelediğinde 98 ihlal kararından 43 adeti belediyelerde çalışan personele ilişkin olduğu görülmektedir. Bu nedenle etik ihlallerin giderilmesi için belediyelerde çalışmaların yoğunlaştırılması gerektiği sonucuna varılmıştır.

Kamu Görevlileri Etik Kurulu tarafindan 2019 y1lı içerisinde Avrupa Birliği ve Türkiye Cumhuriyeti finansman desteği ile Yerel Yönetimler reformu (LAR3) Programı kapsamında,Yerel Yönetimlerde Seçilmiş ve Atanmış Kamu Görevlilerinin Etik Farkındalığının Arttırılması için Teknik Destek Projesi başlatılmıştır. Proje kapsamında Belediyeler öncelikli olmak üzere yerel yönetim birimlerindeki etik ihlal alanları, kamu çalışanları ve sivil halkın etik bilgi ve algının tespiti için ilgili taraflarla çalıştaylar, Yerel yönetimlerde atanmış ve seçilmiş kamu görevlilerine, kent konseyi mensuplarına, vatandaşlara ve yerel yönetim paydaşlarına yönelik olarak Anket Çalışmaları, Akademik Araştırma Çalışmaları ve Mevzuat Boşluk Analizleri gerçekleştirilmiştir (Tablo2.3; KGEK, 2020:21).

KGEK tarafından ilgili proje kapsamında yerel yönetim çalışanları, vatandaşlar ve yerel yönetimlerden hizmet alan hedef gruplardan 5.000 kişi ile yüz yüze gerçekleştirilen anket sonuçlarına göre yerel yönetimlerde etik ihlallerinin en çok yaşandığı hizmet alanları sırasıyla Ihaleler ve Alımlar, İmar Planlama ve Ruhsatlar, İşe Alım ve Sosyal Hizmet Alımları işlemlerinde gerçekleştiği sonucuna varılmıştır.

Tablo 2.3: Yerel Yönetimlerde Seçilmiş ve Atanmış Kamu Görevlilerinin Etik Farkındalığının Arttırılması Proje Faaliyetleri (KGEK, 2019, KGEK, 2020)

\begin{tabular}{|c|c|c|}
\hline FAALIYET ADI & TARİH VE YERİ & KATILIMCILAR \\
\hline $\begin{array}{l}\text { Proje Başlangıç } \\
\text { Toplantısı }\end{array}$ & $\begin{array}{l}16 \text { Ocak } 2019, \\
\text { Ankara }\end{array}$ & KGEK Üyeleri, Proje Uzmanları \\
\hline $\begin{array}{l}\text { Proje Açılış } \\
\text { Töreni. }\end{array}$ & $\begin{array}{l}24 \text { Nisan 2019, } \\
\quad \text { Ankara }\end{array}$ & $\begin{array}{c}\text { T.C. Cumhurbaşkanı Yardımcısı, İçişleri Bakanı, KGEK } \\
\text { Üyeleri, } 81 \text { İlin Mülki İdari Amirleri }\end{array}$ \\
\hline $\begin{array}{l}\text { Proje Basin } \\
\text { Toplantisi }\end{array}$ & $\begin{array}{l}28 \text { May1s 2019, } \\
\text { Ankara }\end{array}$ & KGEK Üyeleri, Proje Heyeti, Basın Temsilcileri \\
\hline \multirow{7}{*}{$\begin{array}{l}\text { Yerel Yönetim } \\
\text { Etik İlkeleri } \\
\text { Çalıştayları }\end{array}$} & $\begin{array}{l}\text { Gaziantep } \\
\text { Çalıștayı,15-18 } \\
\text { Ekim } 2019 .\end{array}$ & $\begin{array}{c}\text { Akdeniz ve Çukurova Bölgesi Belediye Başkan ve } \\
\text { Bürokratları, Ticaret ve Sanayi Oda Temsilcileri, Kent } \\
\text { Konseyleri, İlgili STK'lar }\end{array}$ \\
\hline & $\begin{array}{l}\text { Trabzon Çalıştayı, } \\
\text { 5-8 Kasım } 2019 .\end{array}$ & $\begin{array}{c}\text { Karadeniz Bölgesi Belediye Başkan ve Bürokratları, } \\
\text { Ticaret ve Sanayi Oda Temsilcileri, Kent Konseyleri, İlgili } \\
\text { STK'lar }\end{array}$ \\
\hline & $\begin{array}{l}\text { Erzurum } \\
\text { Çalıştayı, 14-15 } \\
\text { Kasım } 2019 .\end{array}$ & $\begin{array}{l}\text { Doğu Anadolu Bölgesi Belediye Başkan ve Bürokratları, } \\
\text { Ticaret ve Sanayi Oda Temsilcileri, Kent Konseyleri, İlgili } \\
\text { STK'lar }\end{array}$ \\
\hline & $\begin{array}{l}\text { Diyarbakır } \\
\text { Çalıştayı, 10-11 } \\
\text { Aralık 2019. }\end{array}$ & $\begin{array}{c}\text { Güney Doğu Anadolu Bölgesi Belediye Başkan ve } \\
\text { Bürokratları, Ticaret ve Sanayi Oda Temsilcileri, Kent } \\
\text { Konseyleri, İlgili STK'lar }\end{array}$ \\
\hline & $\begin{array}{l}\text { İstanbul Çalıştayı, } \\
\text { 24-27 Aralık } 2019\end{array}$ & $\begin{array}{l}\text { İstanbul İli Belediye Başkan ve Bürokratları, Ticaret ve } \\
\text { Sanayi Oda Temsilcileri, Kent Konseyleri, İlgili STK'lar }\end{array}$ \\
\hline & $\begin{array}{l}\text { İzmir Çalıştayı, 6- } \\
7 \text { Ocak } 2020 .\end{array}$ & $\begin{array}{l}\text { İzmir Valisi, Bölge Belediye Başkan ve Bürokratları, Oda } \\
\text { Temsilcileri, Kent Konseyleri, İlgili STK'lar }\end{array}$ \\
\hline & $\begin{array}{l}\text { Antalya Çalıştayı, } \\
\text { 4-5 Şubat } 2020\end{array}$ & $\begin{array}{l}\text { Sn. Cemil Çiçek, Antalya Valisi, Bölge Belediye Başkan } \\
\text { ve Bürokratları, Oda Temsilcileri, Kent Konseyleri, İlgili }\end{array}$ \\
\hline Mevzuat & 16 Ocak 2020 & Danıştay, Yargıtay, Sayıştay Tetkik Hakimleri, İçişleri, \\
\hline
\end{tabular}




\begin{tabular}{|c|c|c|}
\hline $\begin{array}{c}\text { Çalıştayları } \\
\text { Ankara }\end{array}$ & $\begin{array}{c}\text { 23-25 Haziran } \\
2020 .\end{array}$ & $\begin{array}{c}\text { Çevre ve Şehircilik ve Adalet Bakanlıklarının Hukuk, } \\
\text { Mevzuat ve Teftiş Başkanlığı mensupları, Türkiye } \\
\text { Belediyeler Birliği, Kent Konseyleri Birliği ve Kamu } \\
\text { Görevlileri Etik Kurulu }\end{array}$ \\
\cline { 2 - 2 } & $\begin{array}{c}\text { Uygulama Str. } \\
\text { Çal. 8-9 Temmuz }\end{array}$ & $\begin{array}{c}\text { Almanya Federal Cumhuriyeti Çalışma Ziyareti } \\
\begin{array}{c}\text { Çalışma } \\
\text { Ziyaretleri }\end{array}\end{array}$ \\
\hline
\end{tabular}

Kamu Görevlileri Etik Kurulu tarafından günümüze kadar almış olduğu etik ihlal kararlarının Etik ilkelere göre dağılımı Tablo 2.4'te verilmiştir.

Tablo2.4: Etik İhlal Kararlarının İhlal Edilen Etik İlkelere Göre Dağılımı

\begin{tabular}{|c|c|}
\hline İhlal Edilen Etikİlkeler & $\begin{array}{l}\text { İhlal } \\
\text { Sayısı }\end{array}$ \\
\hline $\begin{array}{l}\text { Görevin yerine getirilmesinde kamu hizmeti bilinci (Yönetmeliğin } 5 . \\
\text { maddesi) }\end{array}$ & 5 \\
\hline Halka hizmet bilinci (Yönetmeliğin 6. maddesi) & 6 \\
\hline Hizmet standartlarına uyma (Yönetmeliğin 7. maddesi) & 12 \\
\hline Amaç ve misyona bağlılık (Yönetmeliğin 8. maddesi) & 7 \\
\hline Dürüstlük ve tarafsızlık (Yönetmeliğin 9. maddesi) & 68 \\
\hline Saygınlık ve güven (Yönetmeliğin 10. maddesi) & 69 \\
\hline Nezaket ve sayg1 (Yönetmeliğin 11. maddesi) & 4 \\
\hline Çıkar çatışmasından kaçınma (Yönetmeliğin 13. maddesi) & 13 \\
\hline $\begin{array}{l}\text { Görev ve yetkilerin menfaat sağlamak amaciyla kullanılmaması } \\
\text { (Yönetmeliğin 14. maddesi) }\end{array}$ & 16 \\
\hline Hediye alma ve menfaat sağlama yasağı (Yönetmeliğin 15. maddesi) & 4 \\
\hline Kamu malları ve kaynaklarının kullanımı (Yönetmeliğin 16. maddesi) & 21 \\
\hline Savurganlıktan kaçınma (Yönetmeliğin 17. maddesi) & 25 \\
\hline Bağlayıcı açıklamalar ve gerçek dışı beyan (Yönetmeliğin 18. maddesi) & 2 \\
\hline Bilgi verme, saydamlık ve katılımcılık (Yönetmeliğin 19. maddesi) & 2 \\
\hline Yöneticilerin hesap verme sorumluluğu (Yönetmeliğin 20. maddesi) & 14 \\
\hline Eski kamu görevlileri ile ilişkiler (Yönetmeliğin 21. maddesi) & 1 \\
\hline İlkelerin ihlal edilme sayısı & 269 \\
\hline Toplam ihlal kararı sayısı & 98 \\
\hline
\end{tabular}




\subsection{Etik Kurul Ve Etik Komisyon Çalişmalari Alan Araştirmasibulgulari Ve Analizi}

Yapılan görüşmeler sonucunda ilk olarak etik komisyon üyelerinin üstlendikleri kamu görevleri, yaş cinsiyet ve eğitim düzeylerine dair demografik bulgulara yer verilmiştir.

\subsubsection{Sosyo-Demografik Bulgular}

Araştırmaya katılan ilgili belediyelerin etik komisyon üyeleri ile ilgili yaş, cinsiyet, öğrenim düzeyi, kamudaki görevleri, kamu görevlisi olarak çalıştığı yıl bilgileri aşağıdaki tablolarda yer almaktadır.

Tablo 2. 5: Görüşme yapılan Etik Komisyon Üyelerinin Yaş Gruplarına Göre Dağılımı

\begin{tabular}{|c|c|}
\hline Yaş Grubu & Sayı \\
\hline $18-30$ & \\
\hline $31-40$ & 1 \\
\hline $41-50$ & 3 \\
\hline $51-65$ & 3 \\
\hline TOPLAM & \\
\hline
\end{tabular}

Etik Komisyon üyelerinin yaş gruplarına göre dağılımı incelendiğinde, çalışanların büyük çoğunluğunun orta yaş olarak nitelendirilen yaş gruplarından oluştuğu tespit edilmiştir. 18-30 yaş arasında genç etik komisyon üyesi bulunmamaktadır. 31-40 yaş arası 1 üye, 41-50 ve 51-65 yaş arası 3'er üye bulunmaktadır.

Tablo 2.6: Etik Komisyon Üyelerinin Cinsiyete Göre Dağılımı

\begin{tabular}{|c|c|}
\hline Cinsiyet & Sayı \\
\hline Erkek & 6 \\
\hline Kadın & 1 \\
\hline TOPLAM & $\mathbf{7}$ \\
\hline
\end{tabular}

Etik Komisyon üyelerinin cinsiyetlere göre dağılımı incelendiğinde sadece 1 kadın komisyon üyesi olduğu tespit edilmiştir. Her iki Büyükşehir Belediyesinde Etik komisyonlar ağırlıklı olarak erkek üyelerden oluşmaktadır.

Tablo2.7: Etik Komisyon Üyelerinin Öğrenim Düzeyine Göre Dağılımları

\begin{tabular}{|c|c|}
\hline & Sayı \\
\hline Lise & \\
\hline Önlisans & \\
\hline Lisans & $\mathbf{6}$ \\
\hline Lisansüstü & $\mathbf{1}$ \\
\hline TOPLAM & $\mathbf{7}$ \\
\hline
\end{tabular}

Etik Komisyon üyelerinin öğrenim düzeylerine göre dağılımı incelendiğinde üyeler arasında İlkokul, ortaokul ve lise mezunu olmadığı, ağırlıklı olarak lisans düzeyinde mezunların olduğu saptanmıştır. 
Tablo2.8:Etik Komisyon Üyelerinin Kurumdaki Unvanlarına Göre Dağılımı

\begin{tabular}{|c|c|}
\hline Ünvan & Sayı \\
\hline Genel Sekreter & 1 \\
\hline Daire Başkanı & 2 \\
\hline Hukuk Müşaviri & 2 \\
\hline İç Denetçi & 1 \\
\hline Müdür & 1 \\
\hline Toplam & $\mathbf{7}$ \\
\hline
\end{tabular}

Araştırmaya konu her iki Büyükşehir Belediyesi Etik Komisyon üyeleri incelendiğinde üyeler arasında 1 Genel Sekreter, 2 Daire Başkanı, 2 Hukuk Müşaviri, 1 İç Denetçi ve 1 Basın yayın Halkla İlişkiler Müdürü olarak kurumlarında görev aldıkları tespit edilmiştir. İlgili Büyükşehir'in Genel Sekreteri aynı zamanda Belediye Etik Komisyonunun Başkanlığı görevini yürütmektedir. Her iki Büyükşehir Belediyesinin İnsan Kaynakları ve Eğitim Daire Başkanı aynı zamanda Etik Komisyon üyesi olarak görev almaktadır. Yine aynı şekilde her iki Büyükşehir Belediyesinin Hukuk Müşavirleri Etik Komisyon üyesidir.

Tablo: 2. 9: Etik Komisyon Üyelerinin Kurumdaki Çalışma Sürelerine Göre Dağılımı

\begin{tabular}{|c|c|}
\hline Çalışma Süresi(Yıl) & Sayı \\
\hline $1-5$ & $\mathbf{1}$ \\
\hline $6-10$ & $\mathbf{2}$ \\
\hline $11-15$ & $\mathbf{2}$ \\
\hline $16-20$ & $\mathbf{2}$ \\
\hline $\mathbf{2 1 - 3 0}$ & - \\
\hline 31 ve üstü & \\
\hline TOPLAM & $\mathbf{7}$ \\
\hline
\end{tabular}

Etik Komisyon üyelerinin kurumdaki çalışma süreleri incelendiğinde üyelerden 1'isi 1-5 y1l arası, 1'si 6-10 yıl aras1, 2'si 11-15 yıl arası, 1'si 16-20 yıl arası, 1'isi 21-30 yıl arasından oluşmaktadır. 31 yıl ve üzeri çalışan etik komisyon üyesi bulunmamak-tadır.

\subsubsection{Etik Komisyon Üyeleri ile Yapılan Görüşme Bulguları ve Analizi}

Çalışmanın bu bölümünde Adana Büyükşehir Belediyesinden 3 Etik Komisyon Üyesi ve Gaziantep Büyükşehir Belediyesinden 3 Etik komisyon üyesi toplam 6 kişi ile yapılan görüşmelerden elde edilen veriler değerlendirilmektedir.

\subsubsection{Türk Kamu Yönetiminde Etik Altyapı ve Etik İhlallerde Kamu Çalışanının Rolüne İlişkin Görüşler}


Kamu yönetiminin temelini oluşturan en önemli unsur kamu hizmeti görevini yerine getirenlerdir. Kamu hizmeti seçilmiş yöneticiler, atanmış bürokratlar ve kamu personeli tarafından sunulmaktadır. Bu hizmetlerin kaliteli ve nitelikli sunumu için çalışanların bir takım değerleri göz önünde bulundurması gerekmektedir. Olumlu ve olumsuz etiğin konusu içerisine giren bu değerlerin etik Altyapı ve Etik İhlallerde Kamu çalışanlarının rolünün saptanması amacıyla komisyon üyelerinin görüşlerine başvurulmuştur.

(...) Kamu'da meydana gelen etik dışı faaliyetlerde kamu görevlilerin rolü büyük, Yönetici konumunda olan bir kamu personeli kendine hediye geldiğinde o hediyenin kendisine makam ve görevinden dolayı geldiği bilincinde olmalı, Tarafsızlık, Ayrımcılık ve Kayırmacılık Yapmamak Temel değerleri gereğince hediyeleri kabul etmemeleri gerekir (Görüşmeci 1).

(...) Kamu faaliyetlerinin yürütülmesi sırasında, kamu görevlilerinin etik dışı işlem veya eylemleri, vatandaşların haklı şikâyetlerine neden olmakta, devlet-vatandaş ilişkilerinin bozulmasına ve halkın kamu kurumlarına güveninin azalmasına neden olmaktadır. Dolayısı ile kamu personelinin etik dışı faaliyette rolü büyüktür. Bu nedenle öncelikle kamu personelinin etik dışı davranışlar konusunda çıkarılan kanun ve yönetmeliklere göre eğitimden geçirilmesi ve hatta Devleti meydana getiren bütün erklerde etkili olacak etik altyapı oluşturulmalı, hesap verme mekanizmalarıyla desteklenip uygulamaya geçmelidir.

(Görüşmeci 2).

(...) Geleneksel hizmet anlayışı devam ettiğinden etik değerlerin önemi personel tarafindan kabulü ve oturması güçleşmekte ve zaman almaktadır (Görüşmeci-3).

(...) Personeller bir işi yaparken karşılık beklemeden yapmalı, bunun kendi görevi olduğu bilincinde olmalıdır (Görüşmeci-4)

(...) Etik dışı faaliyetlerde kamu personelinin rolüne ilişkin değerin farkına vardırılması için özellikle yeni memuriyete alınan personellerle ilgili daha etkin ve farklı bir oryantasyon eğitimine ihtiyaç vardır(Görüşmeci-6).

Görüşmeciler Kamu düzeni oluşturmada Etik Sisteminin önemli rol oynadığı, bu düzeni sağlamada kamu personelinin rolünün büyük olduğu görüşünde hemfikir olmuşlardır. Bu rolün kaynağı olarak kamu etik sisteminin etik dış1 faaliyetleri önlediği, devlet ile vatandaş ilişkilerinde güveni tesis ettiği görüşünü dile getirmişlerdir. Görüşmeciler özellikle yeni atanan personel olmak üzere kamu personellerin etik dı̧̧ faaliyetleri engellenmesi ve bilincin oluşması için etik dışı davranışlar konusunda yeni çıkarılan kanun ve yönetmeliklere göre eğitime tabi olmaları vurgulamışlardır.

\subsubsection{Kamu Etik Komisyonu ve Oluşturulan Etik Sistemine İlişsin Görüşler:}

5176 say1lı Kanun çerçevesinde oluşturulan Türk kamu yönetimi etik sistemi içerisinde belediyeler etik komisyonlarının oluşturulmasının ve etik ilkelerin belirlenmesinin tüm eksiklik ve sıkıntılarına ragmen etik komisyon üyelerinin çoğunluğu tarafından belediyelerde etik farkındalık yaratılması ve konuyla ilgilenen bir oluşumun var olması noktasında katkı sağlayan bir nitelik taşıdığı ifade edilmiştir. Ancak bu düşünce içerisinde olan üyeler her ne kadar kamu yönetimi içerisinde etik sistemin geliştiğini vurgulasa da özellikle uygulama kısmında yeterli olmadığını belirtmişlerdir. Uygulamada etik komisyonun bir yaptırımının olmaması sisteme yapılan eleştirilen başında gelmektedir.

(...) Türk kamu yönetiminde özellikle yerel yönetimlerde oluşturulan Etik Komisyon ve Etik sisteme ilişkin hukuki alt yapı yeterli değil, Kamu'da şu ana kadar gözlemlediğim yapılan işlemin yasal mı? değil mi? Buna bakılıyor. Etik dışı olmamasına bakılmıyor. Dolayısıyla etik olmayan işlemlerin aynı zamanda yasal olmaması lazım. Kanunlar buna göre düzenlenmelidir (Görüşmeci-1).

(...) Yönetmelikte "Kurum ve kuruluşlarda etik kültürünü yerleştirmek ve geliştirmek, personel etik davranış ilkeleri konusunda karşılaştıkları sorunlarla ilgili olarak tavsiyelerde ve yönlendirmelerde bulunmak ve etik uygulamaları değerlendirmek üzere kurum ve kuruluşun üst yöneticisi tarafından kurum içinden en az 3 kişilik bir etik komisyonu oluşturulur" denilmiştir. Komisyonun tanımda belirtilen görevleri yerine getirmesi halinde etkin ve verimli olacağı açıktır (Görüş̧meci 2).

(...) Etik Komisyon çağdaş kamu yönetimleri için gereklidir. Ancak kamu personeli nezdinde etik değerlerle ilgili değerlerin yerleşmesi ve eğitim bazında uzun süreli çalışmalar yapılması gereklidir. Bu haliyle etik komisyon fonksiyon icra etmekten uzaktır (Görüşmeci -3).

(...) Kamu Yönetimi İçin Etik Komisyonların önemi büyüktür. Yasal yoldan karşıllı̆ı (cezası olmayan işler etik komisyona geliyor. Etik ihlale ilişkin alınan kararların kamuoyuna duyurulması sonucu kamuoyu tepkisi personellerin etik ihlal yapması yönünde caydırıcı olabilir (Görüşmeci-4).

(...) Etik komisyonun görev yetki ve yaptırımları yeterli değil. Yapılan etik dışı işlerin bir yaptırımı olması gerekli Kamu zararı oluşturacak ihlal durumlarında kararlar almalı ve bu kararları uygulayabilmelidir (Görüşmeci-6). 


\subsubsection{Kamu Yönetiminde Etik İhlallerin Önlenmesine ilişkin Görüşler.}

Ülkemizde konuya ilişkin olan düzenlemelerin yetersiz olduğu görüşünü savunan kamu görevlilerinin ortak vurgu noktaları hukuki anlamda var olan boşlukların etik dışı faaliyetlerin gerçekleşmesini kolaylaştırdığıdır. Hukuki boşlukların yanı sıra kamu personellerde etik farkındalık ve bilincin oluşmaması ve etik ihllaerin görmezden gelinmesi durumları kamu yönetiminde etik ihlallere yönelik getirilen eleştirilerden olmuştur.

(...) Yapılan düzenleme ve çalışmalar ile hukuki alt yapı yeterli değildir.5176 Sayılı Kanun'da kamu görevlilerinin tabi olacakları etik davranış ilkelerinin yasal çerçevesi çizilmeden, etik ilkeleri tanımlama görevi Kamu Görevlileri Etik Kuruluna bırakılmıştır. Etik davranış ilkelerinin Kanun'da tanımlanması ve ana hatlarını belirlenmesi gerekir. Yasama ve yargı mensupları için de ivedilikle etik yasa ve kodlar yürürlüğe konulmalıdır (Görüşmeci-2).

(...) Kamu'da şu ana kadar gözlemlediğim yapılan işlemin yasal mı? değil mi? Buna bakılıyor. Etik dışı olmamasına bakılmıyor. Dolayısıyla etik olmayan işlemlerin aynı zamanda yasal olmaması lazım (Görüşmeci 1)

(...) Kamudaki önemli görevler ve kariyer mesleklerin her biri için etik değerler belirlenmeli, mesleki icrası ve devamı için etik değerlerin yerine getirilip getirilmediğinin takibi yapılmalıdır (Görüşmeci-3).

(...) Kamu Yönetim sistemimizde özellikle belediyelerde çalışan personellere ilişkin adil ve eşit olacak şekilde ödüllendirme ve cezalandırma yok. etik ihlal oluşumunda bu kültürün yaygınlaşmaması da ana etken (Görüşmeci 4).

(...) Kamu Görevlileri Etik Davranış İlkeleri İle Başvuru Usul Ve Esasları Hakkında Yönetmelik’teki genel olarak belirlenen etik ilkeler yeterli değildir (Görüşmeci 5).

\subsubsection{Görüşme Bulgularının Değerlendirilmesi}

Etik komisyon üyelerine kamu yönetimi özelinde belediyelerde etik komisyon ve etik sistemi altyapısına ve de personellerin sistem içerisindeki rollerinin yanı sıra özellikle Belediye Etik komisyon çalışmalarına getirilen eleştiriler hakkındaki görüşleri, Kamu Görevlileri Etik Kurulu ile etik komisyon çalışmaları hakkındaki düşünceleri ve etik komisyonun işlevselliğini değerlendirmesi konusunda genel düşüncelerine başvurulmuştur.

Görüşmeciler Etik Komisyonlarının kurulmasının ve kamu personeli için etik ilkelerin belirlenmesinin Türk kamu yönetimine katkı sağladığına, fakat yeterli olduğunu düşünmediklerini belirtmişler etik komisyonlarının yaptırımlarının olmasında hem fikir olmuşlardır. Daha kapsamlı yaptırımlar getirilmesini beyan etmişlerdir.

Görüşmelerden elde edilen sonuçlar neticesinde, Etik Komisyonların ve Etik Kurul çalışmalarının kamu personelleri tarafindan yeterince bilinmediği tespit edilmiştir. Ayrıca Kamu Görevlileri Etik Kurulu ile Etik Komisyon arasındaki iletişim ve işbirliği düzeyinin istenilen düzeyde olmadığ 1 görüşmeciler tarafından belirtilmiştir. Bu durum özellikle kamu yönetiminde etik bilincin oluşturulması ve etik farkındalığın arttırılması eğitim ve bilgilendirme çalışmalarına yoğunlaşması gerekliliğini ortaya çıkarmaktadır.

(...)Yerel yönetim bazında ortak bir çalışma veya işbirliğini gerektirecek faaliyet olmamıştır (Görüşmeci-3).

(...) Böyle bir işbirliği olduğunu düşünmüyorum. Kurumlardaki pek çok personelin böyle bir kurul ve komisyondan kurumdaki pek çok personelin haberi olduğunu sanmıyorum (Görüşmeci -1).

Gerek kamu görevlileri etik kurulunun gerekse kamu etik komisyonlarının etik ihlal incelemelerindeki sınırlandırmaların oluşması ve hukuki yaptırımlarının olmaması üyeler tarafindan vurgulanmıştır. Görüşmeciler Etik Komisyonlarının kurulmasının ve kamu personeli için etik ilkelerin belirlenmesinin Türk kamu yönetimine katkı sağladığına, fakat yeterli olduğunu düşünmediklerini belirtmişler etik komisyonlarının yaptırımlarının olmasında hem fikir olmuşlardır. Daha kapsamlı yaptırımlar getirilmesi önerisinde bulunmuşlardır.

Komisyon üyelerinin etik komisyonlara getirmiş olduğu bir diğer eleştiri ise komisyonun özerk yapısının olmamasıdır. Kurulun bu yapısı tarafız çalışmalar yapmasına engel olmaktadır.

(...) Kurul değince akla bağımsız bir yapı gelir ama, etik kurul öğle değildir. Kendisini görevlendirenlerin altındaki personeller üzerinde, teşkilat yasaları ile desteklenen bağımsız bir kurul olmadığı için de işlevsel değildir. Günümüze kadar gelen sınırlı faaliyetleri de bunu teyit etmektedir (Görüşmeci-4)

Etik Komisyon üyeleri Kamu Denetçiliği Kanununun Yürürlüğe girmesinin etik kurul ve etik komisyon işlevlerini etkileyip etkileyemeyeceği yönündeki görüşlerinde yerelde kamu denetiminden ziyade kamuoyu denetiminin etkin hale getirilmesi ile toplumsal baskı unsuru oluşturulabileceği ve etik ihlallerin önlenebileceği görüşü öne sürülmüştür.

Görüşmeciler özellikle kamu yönetiminde etik ihlallerin önlenmesinde personellerin önemli rol oynadığını, kapasite ve yeterliliklerin artması gerektiğini dile getirmişler, yasal zorunluluktan ziyade etik bilincin oluşması ve etik kültürün yaygınlaşması ile etik ihlallerin önüne geçilebileceğini belirtmişlerdir. Bu doğrultuda etik 
kodlara ilişkin eğitim ve bilinçlendirme faaliyetlerinin etik haftasına yoğunlaştırılmaması düzenli ve sistematik hale getirilmesi gerektiğini belirtmişlerdir.

\section{SONUÇ VE DEĞERLENDİRME}

Ülkemizde 1990'l1 y1lların sonundan itibaren başta AB'ye üyelik süreci olmak üzere diğer küresel ve bölgesel nitelikli kuruluşların talepleri ile birlikte, yaşanan ekonomik krizler ve siyasi istikrarsızlıkların da etkisiyle ülkede yolsuzluk ve etik dışı faaliyetlerle mücadele alanında çalışmalar hızlanmıştır. Bu mücadele alanının en somut adım 5176 sayılı Kamu Görevlileri Etik Kurulu Kurulması Hakkında Kanun'un yürürlüğe girmesi akabinde 2005 yılında Kamu Görevlileri Etik Davranış İlkeleri İle Başvuru Usul ve Esasları Hakkında Yönetmeliğin yayımlanmasıdır. Yönetmelik kapsamında Kamu Görevlileri Etik Kurulu teşkil edilmiş, kamu görevlilerinin uymaları gereken etik davranış ilkeleri dağınık bir mevzuattan kurtarılarak gözden geçirilmiş, Kurul'a kamuda etik kültürünün geliştirilmesi ile ilgili birçok görev ve sorumluluk verilmiştir. Aynı amaç doğrultusunda 13/04/2005 tarihinde yürürlüğe giren Kamu Görevlileri Etik Davranış İlkeleri İle Başvuru Usul ve Esasları Hakkında Yönetmeliğin 29'uncu maddesi gereğince diğer kamu kurumlarında olduğu gibi halkın doğrudan karar süreçlerine katılım olanaklarının olduğu yerel yönetim birimlerinin başında gelen belediyelere de Etik Komisyon oluşturma zorunluluğu getirilmiştir.

Kurul'un üst düzey resmi görevlilere ilişkin Resmi Gazetede yayımlamış olduğu etik ilkelerin ihlaline ilişkin kararlar, kamu yöneticilerine ve topluma önemli sorumluluklar yüklemektedir. Kurul'un Cumhurbaşkanlığa bağlı olması ve yetki alanının sınırlılı̆̆ sebepleriyle, Kurul'dan beklenen işlevsellik ve objektiflik henüz sağlanamamıştır. Aynı şekilde 5176 sayılı kanun kapsamında oluşturulan yönetmelik çerçevesinde belediyelerde kurulan Etik komisyonlarda beklenen işlevselliği sağlayamamıştır.

Çalışmada gerek mevzuat ve literatür gerekse etik komisyon üyeleri görüşmelerindeki ifadelerinden hareketle Etik Komisyonların işlevsellik sorunları teşkilat yapısından, mali özerkliğinden ve de yaptırım yetkisinden kaynaklandığını söylemek mümkündür. Etik komisyonların ve kurulların işlevsel anlamda güçlü olmaları öncelikle bağımsız ve özerk olmalarına bağlıdır. Yapılan görüşmelerde tespit edilmiştir ki, komisyon üyelerinin yeterlikleri ve uzmanlıkları konusunda hiçbir şüpheye mahal yoktur. Ancak teşkilatlanma konusunda Türk idari sisteminde var olan bağımsız komisyonlar gibi etik komisyonlar için de en uygun model belirlenmelidir.

Belediyeler Etik Komisyonlara karşı getirilen eleştirilerin başında komisyonun cezai bir yaptırım gücünün olmaması gelmektedir. Çok sayıda ülke son yıllarda etik davranış kodları ihlallerine karşı somut yaptırım mekanizmaları oluşturmuştur. Örneğin Japonya'da 1999 yılında Ulusal Kamu Hizmeti Yasasıyla oluşturulan ve üyeleri bakanlar Kurulu tarafından atanan Ulusal Kamu Hizmeti Etik Kurulu, Kanuna aykırı eylemleri doğrudan inceleme ve disiplin cezası verme yetkisine sahip olduğu gibi kurumlardan etik ilke ihlali iddialarını incelemelerini ve gerekiyorsa disiplin cezaları vermelerini de isteyebilmektedir.

Çalı̧̧ma Kapsamında tespit edilen bir diğer önemli sorun ise belediye etik komisyonlarının yönetmelik hükmüne göre kurulmasıdır. Bu durum etik komisyonların güçlü bir yasal dayanağının oluşturmasına engel olmaktadır. Dolayısıyla belediyelerde, üyeler kurum üst yöneticileri tarafinda belirlenmektedir. Kurum üst yetkilisi emrinde belirlenen ve çalışmalar yürüten etik üyelerinin kurum içi etik ihlal uygulamalarını değerlendirmelerinde tarafsız davranılması beklenilen bir durum olarak görülmektedir. Bu nedenle Belediyelerde Etik Komisyon üyeleri Kurum üst yöneticisinin atamasından ziyade belediye karar organı olan Belediye Meclis üyelerinin seçimi ile belirlenmelidir. İlgili yönetmelikteki yasal dayanak yönünden sorunlu bir başka hükümde zaman aşımını düzenleyen "oluştuğu tarihi izleyen günden başlayarak iki yıl içinde yapılmayan etik ilkelere aykırı davranışlar hakkındaki başvurular incelenmez" içerikli 40’ maddedir. $\mathrm{Bu}$ maddeninde gözden geçirilerek etik ihlal incelemelerinde zaman aşımının kaldırılması gerektiği kanısı yaygınlaşmıştır.

Etik değerlere dayalı bir kurum kültürü oluşmasında en önemli faktör eğitim olarak görülmektedir. Etik eğitimlerinin etik değerlere dayalı kurum kültürü oluşmasına da katkısı vardır. Bu nedenle Etik değer ve etik uygulamalar konsunda personel eğitimlerine ağırlık verilmelidir.

Çalışma kapsamında elde edilen veriler ışığında Belediyelerde etik ihlallerinin en çok yaşandığı hizmet alanları sırasiyla Ihaleler ve Alımlar, İmar Planlama ve Ruhsatlar, İşe Alım ve Sosyal Hizmet Alımları işlemlerinde gerçekleştiğini söylemek mümkündür. Etik Komisyonların ve Kamu Görevlileri Etik Kurulu'nun bu alanlardaki etik ihlallerin önüne geçebilmesi için özellikle ilgili personellere Etik Bilincin ve farkındalı̆̆ın oluşacak eğitim ve bilgilendirme çalışmalarına yoğunlaşmaları gerektiği vurgulanması gereken bir başka husustur. Bu çalışmalar özellikle Kamu Görevlileri Etik Kurulu ve Kamu Etik Komisyonlarının koordinasyonunda gerçekleşmelidir. Eğitim faaliyetlerinin yanı sıra diğer faaliyetlerde de iletişim ve işbirliği düzeyi arttırılmalıdır. 
Yerel Yönetimlerde Etik İhlallerin önlenebilmesi için katılımcılık ve hesap verme mekanizmaları oluşturulmalıdır. Katılımcılık bağlamında çeşitli ülkelerde iyi uygulama örnekleri bulunan "semt meclisleri", Mahalle Meclisleri ve Kent Konseyleri uygulamaları yerel yönetimler ve sivil toplum kuruluşları tarafindan desteklenmelidir. Katılımcılığı esas alan yapıda oluşan kent konseyleri aracılığıyla yerel yönetim birimi belediyelerde sivil denetim mekanizması olarak kamuoyu denetimi gerçekleştirilebilir. Şeffaf ve Hesap verebilir belediyelerde oluşması ihtimal etik ihlallerin önüne geçmek mümkündür. Bu amaçla, Etik kültürünü güçlendirmek ve yolsuzluğu en aza indirmek üzere sivil toplum kuruluşları ve yerel yönetimlerin ilgili aktörleri arasında sürdürülebilir iş birliğinin sağlanmasına ilişkin geniş bir stratejide sürdürülebilir bir işbirliği ağı oluşturulabilir.

Etik değerlere dayalı bir kurum kültürü oluşmasında en önemli faktör eğitim olarak görülmektedir. Etik eğitimlerinin etik değerlere dayalı kurum kültürü oluşmasına da katkısı vardır. Bu nedenle Etik değer ve etik uygulamalar konsunda personel eğitimlerine ağırlık verilmelidir. Kamu görevlileri Etik kurulu tarafindan yerel yönetimler için etik davranış kurallarını ve etik bir yerel yönetim sisteminin uygulanmasında gerek duyulabilecek konulara ilişkin hazırlanan Etik Rehber tüm çalışanların bilgisine sunulmalıdır.

Etik değerlerin kurum aidiyatı sağlama üzerinde de önemli bir misyonunun olduğunu söyleyebilinmektedir. Etik dışı davranışta bulunan personellere yaptırım uygulanması beklenildiği gibi aynı şekilde çalışmalarda etik bilinçle hareket eden personellerin ödüllendirilmesi yoluyla teşvik edilmesi kurum kültüründe etik uygulamaları arttıracaktır.

\section{KAYNAKÇA}

AKDENIZ, İbrahim (2016), “Türkiye'de Yerel Yönetimler Tarafindan Hizmet Sunumu Esnasinda Gerçekleştirilen Etik Ihlalleri Araştırma Raporu”, Sayıştay Dergisi, S (103), ss. 59-83.

AKTAN, Coşkun C,(1999), Ahlaki Yeniden Yapılanma ve Toplam Ahlaka Doğru: 3-Siyasal Ahlak, Arı Düşünce ve Toplumsal Gelişim Derneği Yayınları, İstanbul.

AYDIN, Pehlivan, İ. (2012), Yönetsel Mesleki Ve Örgütsel Etik, PEGEM Yayınları, Ankara, 5.Bask1.

DOĞAN, Özlem (2010), Etik Ahlak Felsefesi, Say Yayınları, İstanbul.

KAHRAMAN, Seden (2010), “Türk Kamu Yönetiminde Yolsuzlukla Mücadelede Hukuki Ve İdari Düzenlemelerin Etkisi, Kocaeli Üniversitesi Sosyal Bilimler Enstitüsü, Yüksek Lisans Tezi, Kocaeli.

Kamu Görevlileri Etik Davranış İlkeleri ile BaşvuruUsul ve Esasları Hakkında Yönetmelik, (13.04.2005 tarihli ve 25785 say1l Resmi Gazette).

KÜÇÜKYAĞCI, Nazmi (2017), “Bir Politika Transferi Örneği Olarak Türkiye'de Etik Yapılanma” Uluslararası Kamu Yönetimi Forumu, S (14).

KILAVUZ, Raci (2003), Kamu Yönetiminde Etik ve Bir Sorun Alanı Olarak Yozlaşma, Seçkin Yayıncılık, Ankara.

OECD (1998), "Principles for Managing Ethics in the Public Service" OECD Recommendation, https://www.oecd.org/gov/ethics/oecdprinciplesformanagingethicsinthepublicservice.htm.

ÖZTÜRK, A. Turan (2009), Türk Kamu Yönetiminde Yolsuzluk Ve Rüşvetin Önlenmesinde Bir Kontrol Aracı Olarak İç Denetimin Rolü, TODAİE Yayınları, Ankara.

PUSTU, Yusuf, (2005), "Yerel Yönetimler ve Demokrasi”. Sayıştay Dergisi, S (57), ss. 121-134.

T.C 1982 Anayasası, (09.11.1982 tarihli ve 17863 sayılı Resmi Gazete).

YATKIN, Ahmet, (2008), “Etik Düşünce Ve Davranışın Yerel Yönetimlerde Hizmet Verimliliğinin Arttırılmasında Rolü ve Önem Elazı̆̆ Belediyesi Örnek Alan Araştırması” Firat Üniversitesi Sosyal Bilimler Dergisi, S (1), ss. 211-231.

YÜKSEL, Cüneyt (2005), Devlette Etikten Etik Devlete: Kamu Yönetiminde Etik, TUSİAD Yayınları, Ankara.

657 Say1lı Devlet Memurları Kanunu, (23.07.1965 tarihli ve 12056 sayılı Resmi Gazete). 
3628 Sayılı Mal Bildiriminde Bulunulması, Rüşvet Ve Yolsuzluklarla Mücadele Kanunu,( 04.05.1990 tarihli ve 20508 say1l1 Resmi Gazete).

5176 sayılı Kamu Görevlileri Etik Kurulu Kurulmasi Ve Bazı Kanunlarda Değişiklik Yapılması Hakkında Kanun, (08.06.2004 tarih ve 25846 sayılı Resmi Gazete).

5237 say1lı Türk Ceza Kanunu, (12.10.2004 tarihli ve 25611 sayılı Resmi Gazete). 